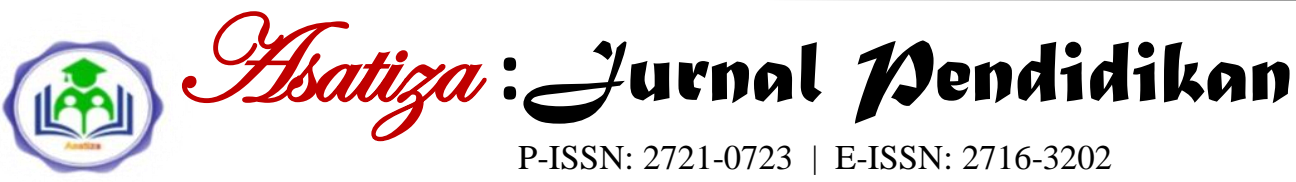 \\ https://ejournal.stai-tbh.ac.id/index.php/asatiza
}

\section{Dampak Budaya Kampus terhadap Keputusan Mahasiswa Memilih Tempat Kuliah}

\author{
*Iwan Siswanto ${ }^{1, a}$, Lias Hasibuan ${ }^{2, \text { b }}$, Kasful Anwar US ${ }^{3, c}$, M. Ridhwan ${ }^{4, d}$ \\ ${ }^{1}$ STAI Auliaurrasyidin Tembilahan, Indragiri Hilir, Riau, Indonesia \\ ${ }^{2,3}$ UIN Sulthan Thaha Saifuddin, Jambi, Indonesia \\ ${ }^{4}$ STAI Auliaurrasyidin Tembilahan, Indragiri Hilir, Riau, Indonesia \\ aiwansiswanto50@gmail.com, ${ }^{b}$ lhas10@yahoo.co.id, ${ }^{c}$ kasfulanwarus@gmail.com, ${ }^{\mathrm{d}}$ ridhwan@stai- \\ $\underline{\text { tbh.ac.id }}$

\begin{tabular}{|c|c|}
\hline $\begin{array}{l}\text { INFORMA } \\
\text { ARTIKEL }\end{array}$ & \\
\hline Histori Arti & kkel: \\
\hline Diterima : & : 18/01/2021 \\
\hline Direvisi & : 28/04/2021 \\
\hline Disetujui : & :06/05/2021 \\
\hline Diterbitkan : & : 27/05/2021 \\
\hline
\end{tabular} \\ Keywords: \\ Campus, Culture, \\ Student, Decisions \\ Kata Kunci: \\ Kampus, Budaya, \\ Mahasiswa, Keputusan \\ DOI: \\ https://doi.org/10.46963/ \\ asatiza.v2i2.292 \\ *Correspondence \\ Author: \\ iwansiswanto50@gmail \\ .com

\begin{abstract}
The purpose of this study was to determine the effect of campus culture on students' decisions to study at STAI Auliaurrasyidin Tembilahan. This study used a quantitative design by random sampling based on the proportions of Isaac and Michael with a significant level of 5\% totaling 238 from a population of 748. Questionnaires were used to collect the data in this research and analyzed using simple regression analysis. The results showed that there was a significant cultural influence on student selection decisions. The results also showed that students' organizations did not attract students' interest in making choices. Therefore, the campus should make culture a tool to make excellence and characteristics that can be used as promotional material to increase the number of students.

\section{Abstrak}

Tujuan penelitian ini yaitu untuk mengetahui pengaruh budaya kampus terhadap keputusan mahasiswa masuk di STAI Auliaurrasyidin Tembilahan. Penelitian ini menggunakan desain kuantitatif dengan pemilihan responden secara acak berdasarkan proporsi Isaac dan Michael dengan taraf signifikan 5\% berjumlah 238 dari populasi 748. Teknik pengumpulan data menggunakan angket yang kemudian diolah dan dianalisis menggunakan analisis regresi sederhana. Hasil penelitian menunjukkan terdapat pengaruh budaya secara signifikan terhadap keputusan pemilihan mahasiswa. Hasil penelitian juga menunjukkan bahwa organisasi kemahasiswaan kurang menarik minat mahasiswa dalam menentukan pilihan. Oleh karena itu, kampus harusnya menjadikan budaya sebagai alat untuk membuat keunggulan dan membentuk karakteristik kampus yang dapat dijadikan bahan promosi demi meningkatkan kuantitas mahasiswa.
\end{abstract}

\section{Cara mensitasi artikel:}

Siswanto, I., Hasibuan, L., USK. A., \& Ridhwan, M. (2021). Dampak budaya kampus terhadap keputusan mahasiswa memilih tempat kuliah. Asatiza: Jurnal Pendidikan, 2(2), 116-123. https://doi.org/10.46963/asatiza.v2i2.292

\section{PENDAHULUAN}

Pada saat ini calon mahasiswa mempunyai banyak pertimbangan dalam memilih sebuah kampus sebagai tempat tujuannya dalam melanjutkan studinya. Adanya pertimbangan tersebut dikarenakan saat ini jumlah kampus negeri maupun swasta sangat banyak. Provinsi Riau memiliki empat PTN dan lebih dari 157 PTS yang tersebar dibeberapa kabupaten dan kota. Pertimbangan tersebut dilakukan agar keputusan pemilihan terhadap kampus sesuai dengan kebutuhan dan kemampuannya. 
Keputusan perilaku konsumen mencakup proses pengambilan keputusan dan kegiatan yang dilakukan konsumen secara fisik dalam pengevaluasian, perolehan penggunaan atau mendapatkan barang dan jasa (Suryani 2008). Sehingga lembaga pendidikan tinggi harus mampu mengetahui kebutuhan pelanggannya.

Banyaknya kampus negeri dan swasta memberi implikasi terjadinya persaingan antar kampus dalam mendapatkan calon mahasiswa. Provinsi Riau memiliki 4 kampus dengan status negeri dan 157 berstatus swasta. Maka yang terjadi adalah beberapa kampus bisa berkembang dan menjadi besar sehingga dengan mudah mendapatkan banyak prestasi, tetapi banyak pula yang tidak mampu bersaing. Persaingan di dunia pendidikan tidak dapat terelakkan lagi, banyak lembaga pendidikan tinggi yang ditinggalkan oleh pelanggannya sehingga dalam beberapa tahun ini banyak terjadi merger dari beberapa lembaga pendidikan tinggi. Institusi pendidikan sebagai salah satu bentuk usaha jasa, seperti organisasi lainnya tidak lepas dari pengaruh globalisasi dan kompetisi.

Perubahan yang sangat pesat dari adanya beberapa kebijakan pemerintah yang mendukung perubahan mengharuskan institusi pendidikan berbenah diri. Hal ini sesuai dengan Permendikbud 7 tahun 2020 tentang pendirian, perubahan dan pembubaran Pendidikan Tinggi, maka dalam menghadapi persaingan dalam dunia pendidikan, kampus dituntut dapat mengembangkan lembaganya terutama persaingan dalam hal memperoleh mahasiswa. Karena pada kampus swasta jumlah mahasiswa sangat menentukan bertahan atau tidaknya lembaga tersebut. Sehingga untuk menghadapi masalah yang ada, kampus harus mengenali target sasaran yang menjadi konsumen lembaga pendidikan tinggi.

Dalam pengambilan keputusan, konsumen pendidikan mulai lebih teliti dengan cara lebih memilih dan menuntut mana lembaga pendidikan yang benarbenar sesuai. Hal ini menjadi proses pengambilan keputusan dari konsumen pendidikan yang dipengaruhi oleh faktor luar. Sehingga mengarahkan konsumen pendidikan untuk memilih sesuai dengan keinginannya.

Maka dari itu dengan adanya masalah tersebut sebuah lembaga pendidikan tinggi harus mengetahui proses pengambilan keputusan konsumen dalam memilih lembaga pendidikan. Hal ini dapat diketahui dengan cara mengkaji faktor-faktor yang mempengaruhi perilaku konsumen terkait dengan keputusan konsumen pendidikan. Menurut Buchari Alma (Alma, 2009) mengungkapkan bahwa terdapat empat faktor yang mempengaruhi perilaku konsumen. Keempat faktor tersebut di antaranya adalah faktor budaya, sosial, pribadi, dan psikologi. Kemudian (Kotler \& Keller, 2009) mengungkapkan bahwa perilaku konsumen hanya dipengaruhi oleh tiga faktor saja, yakni faktor budaya, sosial, dan pribadi.

Budaya memberikan pengaruh paling luas dan mendalam pada tingkah laku konsumen. Hal ini didukung hasil penelitian oleh Hutagalung dan Aisha (2008); Suprayitno, dkk (2015); dan Pratiwi \& Mandala (2015). Penelitian 
tersebut mendukung bahwa budaya merupakan faktor yang paling dasar untuk menentukan keinginan dan perilaku individu. Budaya memberikan norma bagi individu sehingga setiap individu memiliki ciri khas yang berbeda dalam aturan hidupnya. Ciri khas itulah yang menjadi dasar konsumen untuk menentukan keputusan. Budaya kaitannya dengan keputusan konsumen dalam pemilihan lembaga pendidikan tinggi adalah menyesuaikan antara budaya kampus dengan kehidupannya. Sehingga dari budaya kampus yang sesuai dengan dirinya terbentuk sebuah keputusan.

Menurut Alma dan Hurriyati (2008) Apabila melihat lembaga pendidikan dari kacamata sebuah corporate, maka lembaga pendidikan ini adalah suatu organisasi produksi yang menghasilkan jasa pendidikan yang dipilih oleh para pelanggan pendidikan. Apabila lembaga pendidikan tidak mampu memasarkan hasil output-nya, dalam hal ini jasa pendidikan, disebabkan karena mutunya tidak disenangi oleh pelanggan, tidak memberikan nilai tambah bagi peningkatan pribadi individu, layanan tidak memuaskan, maka output jasa yang ditawarkan tidak akan laku. Akibatnya kampus akan mundur, peminat tidak ada, akhirnya kampus itu ditutup.

Jika sebuah lembaga pendidikan dalam menjalankan perannya sebagai jasa pendidikan tidak mampu memuaskan pelanggannya sesuai dengan kebutuhan lingkungan sosialnya, maka lembaga pendidikan tersebut tidak akan dapat bertahan. Penggunaan istilah pemasaran saat ini sudah sangat berkembang di semua sektor kegiatan. Konsep pemasaran intinya adalah memuaskan konsumen, tidak memperlakukan peserta didik semaunya pimpinan kampus, tapi bagaimana pimpinan kampus mengetahui dan meneliti apa sebenarnya keinginan dari para mahasiswa (konsumennya).

Lembaga Pendidikan Tinggi adalah sebuah kegiatan yang melayani konsumen. Dengan demikian, kampus sebagai lembaga pendidikan tinggi perlu melakukan suatu cara untuk mengetahui kebutuhan konsumen dilihat dari perilaku pelanggan pendidikan dengan memakai dasar pemikiran yang logis. Studi konsumen dapat dijadikan sebagai alat untuk memperbaiki dan mengenalkan produk atau jasa, menetapkan harga, perencanaan saluran, dan lain sebagainya. Maka dari itu dengan memahami bagaimana konsumen mengambil keputusan maka dapat dijadikan sebagai suatu pendekatan dalam menarik calon mahasiswa. Dalam artikel ini, penulis berfokus pada faktor budaya kaitannya dengan keputusan konsumen pendidikan (mahasiswa) di STAI Auliaurrasyidin Tembilahan Riau.

Sekolah Tinggi Agama Islam Auliaurrasyidin Tembilahan berada di Provinsi Riau bagian Wilayah Timur tepatnya di Kabupaten Indragiri Hilir merupakan salah satu kampus swasta di bawah lingkungan Kopertais XII RiauKepri. Keberadaannya tidak akan lepas dari persaingan yang sangat ketat terutama dengan kampus yang ada di Wilayah Barat Provinsi Riau, seperti Universitas Islam Indragiri, Institut Agama Islam ArRisalah, Akademik Kebidanan Husada Gemilang dan kampus swasta lainnya. 
Iwan Siswanto, dkk

Berdasarkan hasil survei pada Pangkalan Data Pendidikan Tinggi (PDDikti) dapat diketahui jumlah mahasiswa STAI Auliaurrasyidin Tembilahan mengalami penurunan peminat. Hal ini dapat dilihat dari jumlah mahasiswa baru pada Tahun Akademik 2017/2018 sebesar 279, kemudian Tahun Akademik 2018/2019 sebesar 268, diikuti Tahun Akademik 2019/2020 sebesar 266, dan pada Tahun Akademik 2020/2021 terus mengalami penurunan dengan jumlah pendaftar sebanyak 214. Kondisi ini mutlak memerlukan strategi pemasaran jasa yang handal agar mampu bersaing dan tetap bertahan. Untuk itu STAI Auliaurrasyidin Tembilahan Riau harus mampu mengetahui faktor-faktor yang menjadi kunci sukses pemasaran jasa, yaitu dengan mengetahui posisi STAI Auliaurrsyidin di benak khalayak sasaran dengan melakukan pendekatan melalui budaya. Untuk menarik calon mahasiswa, selama ini STAI Auliaurrasyidin Tembilahan hanya menggunakan beberapa variabel dalam bauran komunikasi pemasaran antara lain adalah periklanan, humas/publisitas, brosur, dan poster.

Berdasarkan uraian di atas maka artikel ini fokus permasalahannya adalah apakah faktor budaya berpengaruh secara signifikan terhadap keputusan pelanggan pendidikan (mahasiswa) dalam memilih STAI Auliaurrasyidin Tembilahan Riau sebagai lembaga pendidikan tinggi dalam melanjutkan studinya.

\section{METODE}

Jenis penelitian ini adalah penelitian kuantitatif deskriptif yaitu, suatu proses menemukan pengetahuan yang menggunakan data berupa angka sebagai alat menemukan keterangan mengenai apa yang ingin diketahui (Darmawan, 2019). Metode ini disebut metode kuantitatif karena data penelitian berupa angka-angka dan analisis menggunakan statistik (Sugiyono 2012). Jenis penelitian kuantitatif deskriptif dalam penelitian ini digunakan untuk memberikan gambaran bahwa budaya berpengaruh terhadap keputusan pelanggan pendidikan (mahasiswa) masuk di STAI Auliaurrasyiidn Tembilahan Riau.

Penelitian ini dilaksanakan di Sekolah Tinggi Agama Islam (STAI) Auliaurrasyidin Tembilahan Riau. Penelitian menggunakan pendekatan regresi sederhana, dengan budaya sebagai variabel bebas dan keputusan pelanggan pendidikan sebagai variabel terikatnya. Populasi berjumlah 748 mahasiswa dengan menentukan sampel penelitian menggunakan teknik sampel proporsi Isaac dan Michael dengan taraf signifikan $5 \%$ berjumlah 238. Untuk mengetahui apakah ada pengaruh atau tidak antara budaya dengan keputusan pelanggan pendidikan, maka dari itu peneliti menggunakan angket sebagai instrumen penelitian. Hasil penelitian di analisa secara kuantitatif deskriptif.

\section{HASIL DAN PEMBAHASAN}

Hasil penelitian menunjukkan bahwa dalam perhitungan statistik menunjukkan mean dari pengaruh budaya terhadap keputusan pelanggan sebesar 73,46 . Hasil tersebut berada pada interval 61-84 dan menghasilkan kesimpulan dari nilai mean bahwa budaya dalam mempengaruhi keputusan pelanggan masuk pada kategori cukup baik. 
Kemudian nilai mean dari keputusan pelanggan diperoleh 36,892 yang berada pada interval 27-45. Artinya bahwa variabel keputusan pelanggan pendidikan tergolong cukup baik.

Pada pembahasan analisis butir variabel budaya, diketahui dua indikator dengan frekuensi jawaban terendah berada pada indikator organisasi kemahasiswaan yang memiliki jumlah frekuensi yakni sebesar 125 responden mengatakan setuju dan 436 responden mengatakan tidak setuju. Selanjutnya indikator lingkungan membaca yang memiliki frekuensi sebesar 179 responden mengatakan setuju dan 430 responden mengatakan tidak setuju. Dengan hasil analisis butir ini dapat menunjukkan bahwa organisasi kemahasiswaan di STAI Auliaurrasyidin kurang memberikan pengaruh kepada mahasiswa untuk pemilihan kampus. Kemudian indikator lingkungan membaca (Perpustakaan) bukan sarana yang dipakai mayoritas mahasiswa di STAI Auliaurrasyidin. Dengan demikian dapat diketahui bahwa mahasiswa yang kuliah di STAI Auliaurrasyidin Tembilahan belum mengetahui sepenuhnya tentang sarana dan prasarana yang menunjang dalam pembelajaran serta pengetahuan mahasiswa. Hal ini menunjukkan kurang meluasnya komunikasi antara STAI Auliaurrasyidin dengan komunitas masyarakat luas di daerah menjadi salah satu faktor semakin menurunnya jumlah mahasiswa dari tahun ke tahun.

Selanjutnya, hasil dari perhitungan korelasi product moment pearson menghasilkan rxy 0,470 > rtabel yakni 0,235 . Hasil tersebut berkisar antara $0,40-$ 0,599 dan nilai r menunjukkan positif yang berarti bahwa terdapat korelasi positif yang sedang antara budaya terhadap keputusan pelanggan pendidikan dalam memilih kampus. Jadi dapat disimpulkan bahwa semakin tinggi nilai budaya yang ada maka semakin meningkat keputusan pelanggan dalam memilih kampus. Kemudian hasil dari rxy diformulasikan ke dalam hitungan persen (\%) yang disebut $\mathrm{R}$ Square maka hasilnya adalah $22,1 \%$. Jadi kontribusi dari budaya terhadap keputusan pelanggan pendidikan sebesar $22,1 \%$ dan sisanya $77,9 \%$ dipengaruhi oleh faktor lain. Hasil perhitungan dari analisis regresi sederhana adalah pertama, didapat persamaan regresi $Y=126,166+0,332 X$. Hal ini dapat diartikan jika $X=0$ maka nilai budaya sebesar 126,166 yang berarti bahwa jika budaya itu tidak ada maka keputusan pelanggan pendidikan dalam memilih kampus sebesar 0,332. Namun apabila nilai budaya $(X)=25$ maka nilai rata-rata keputusan pelanggan dalam memilih kampus adalah $\mathrm{Y}=126,166+$ $(0,332)(25)=134,466$. Jadi dapat disimpulkan bahwa semakin tinggi nilai budaya maka semakin tinggi pula keputusan mahasiswa dalam memilih kampus.

Kemudian hasil perhitungan secara simultan (keseluruhan) didapatkan kesimpulan bahwa budaya berpengaruh terhadap keputusan pelanggan pendidikan, karena hasil uji F diperoleh sebesar 19,863 Ftabel 3,98 pada taraf signifikansi 5\%. Dengan demikian berarti ada pengaruh yang signifikan dari budaya terhadap keputusan pelanggan pendidikan dalam memilih kampus. Berdasarkan hasil perhitungan koefisien regresi sebesar 0,221 dengan tingkat signifikansi t sebesar 
$(4,470>1,658)$ disimpulkan bahwa pengujian hipotesis pada hipotesis pertama yang berbunyi faktor budaya berpengaruh signifikan terhadap keputusan pelanggan pendidikan dapat diterima.

Secara teori telah disampaikan oleh Thamrin (Abdullah \& Tantri 2012) mengatakan bahwa karakteristik dan proses pengambilan keputusan konsumen menghasilkan keputusan konsumen tertentu. Oleh sebab itu Koentjananingrat mengungkapkan langkah konkret untuk mewujudkan budaya di lembaga pendidikan adalah upaya pengembangan dalam tiga tataran, yaitu tataran nilai yang dianut, tataran praktik keseharian, dan tataran simbol-simbol budaya (Fathurrohman, 2016).

Secara empiris terlihat bahwa dalam tataran nilai STAI Auliaurrasyidin Tembilahan menuangkan seluruh tatanan yang ada pada tata tertib kampus yang kemudian diwujudkan dalam tataran praktik keseharian dalam bentuk sikap dan perilaku keseharian oleh semua warga kampus, seperti himbauan untuk istirahat dari semua aktivitas kampus termasuk perkuliahan ketika suara azan telah berkumandang, serta kegiatan sehari-hari berupa pembiasaan membaca, diskusi dan lain-lain. Pada tataran simbol juga terwujud melalui seragam yang menutup aurat. Dengan adanya tataran budaya yang baik diharapkan dapat menjadi sarana untuk mentransfer nilai kepada mahasiswa serta dapat diterapkan dalam kehidupan sehari-harinya di luar kampus. Sehingga masyarakat atau keluarga yang melihat akan dapat mempengaruhi perspektif yang baik terhadap kampus. Serta diharapkan akan memberikan pengaruh dalam memutuskan memilih STAI Auliaurrasyidin Tembilahan sebagai kampus yang akan digunakan.

Dilihat dalam konteks manajemen pemasaran, Kotler dan Keller menjelaskan bahwa "pemasaran harus benar-benar memperhatikan nilai-nilai budaya untuk memahami cara terbaik memasarkan produk lama dan mencari peluang untuk produk baru." (Kotler \& Keller 2009). Pada penerapan dalam dunia pendidikan penciptaan budaya di kampus yang terencana akan menambah kompetensi mahasiswa dalam mengimplementasikan norma-norma agama Islam dalam kehidupan sehari-hari. Jadi budaya yang ada di STAI Auliaurrasyidin Tembilahan seperti; budaya membaca dan budaya berorganisasi mahasiswa merupakan hal positif yang dapat juga dijadikan alat untuk membuat keunggulan serta membentuk karakteristik kampus yang dapat dijadikan bahan promosi demi meningkatkan kuantitas peserta didik.

\section{SIMPULAN}

Terdapat pengaruh positif dan signifikan faktor budaya terhadap keputusan pelanggan (mahasiswa) dalam memilih STAI Auliaurrasyidin Tembilahan. Hal ini ditunjukkan dengan: 1) Tingkat korelasi (hubungan) sebesar 0,470 dalam kategori sedang karena berada pada rentang $0,40-0,599$. 2) Didapat $R$ Square sebesar $22,1 \%$, jadi kontribusi dari budaya terhadap keputusan pelanggan pendidikan dalam memilih STAI Auliaurrasyidin Tembilahan sebesar $22,1 \%$ dan sisanya sebesar $77,9 \%$ dipengaruhi oleh faktor lain. 3) Nilai Fhitung sebesar 19,863 > Ftabel sebesar 3,98 pada taraf signifikansi 5\%. Sehingga 
dapat dinyatakan bahwa variabel budaya mempunyai pengaruh positif dan signifikan terhadap keputusan pelanggan pendidikan. 4) Nilai thitung sebesar 4,470 $>$ ttabel 1,658 menunjukkan bahwa (Ha) yang berbunyi "ada pengaruh yang signifikan antara budaya terhadap keputusan mahasiswa memilih STAI Auliaurrasyidin Tembilahan" dapat diterima.

Penulis mencoba memberikan rekomendasi sebagai berikut: 1) Variabel budaya diketahui bahwa pada indikator organisasi kemahasiswaan, memiliki jumlah frekuensi yang rendah yakni sebesar 82 responden mengatakan setuju dan 156 responden mengatakan tidak setuju bahwa terdapat organisasi kemahasiswaan yang disukai. Berdasarkan hal tersebut sebaiknya pihak kampus bisa menghidupkan program organisasi kemahasiswaan, mengembangkan segala kegiatan organisasi kemahasiswaan menjadi lebih maju, dan mempromosikan semua organisasi kemahasiswaan yang ada. 2) Memanfaatkan lingkungan membaca juga menjadi item yang memiliki frekuensi paling rendah, yakni sebesar 97 responden mengatakan setuju dan 141 responden mengatakan tidak setuju. Berdasarkan hal tersebut sebaiknya pihak kampus tidak hanya perpustakaan yang menjadi tempat membaca, akan tetapi juga harus bisa menjadikan lingkungan kampus menjadi taman terbuka untuk membaca mahasiswa, dengan menyediakan di berbagai lingkungan kampus "kursi baca".

Bagi yayasan, setelah mengetahui hasil dari tanggapan responden mengenai variabel budaya sebesar $22,1 \%$ hendaknya yayasan lebih meningkatkan strategi pemasaran, kualitas layanan dan mutu program studi guna kemajuan dan perkembangan lembaga pendidikan tinggi yang dikelolanya.

\section{REFERENSI}

Abdullah, T., \& Tantri, F. (2012). Manajemen pemasaran. Depok: PT Raja Grafindo Persada.

Alma, B. (2009). Manajemen Pemasaran dan Pemasaran Jasa. (Rev. Ed). Cetakan Kelima. CV. Alfabeta. Bandung.

Alma, B., \& Hurriyati, R. (2008). Manajemen corporate dan strategi pemasaran jasa pendidikan: Fokus pada mutu dan layanan prima. Bandung: Alfabeta.

Darmawan, D. (2013). Metode Penelitian Kuantitatif. Bandung: PT Remaja Rosdakarya

Fathurrohman, M. (2016). Pengembangan budaya religius dalam meningkatkan mutu pendidikan. Ta'allum: Jurnal Pendidikan Islam, 4(1), 19-42. https://doi.org/10.21274/taalum.201 6.4.1.19-42

Hutagalung, R. B., \& Aisha, N. (2008). Analisis faktor faktor yang mempengaruhi perilaku konsumen terhadap keputusan menggunakan dua ponsel (GSM dan CDMA) pada mahasiswa Departemen Manajemen Fakultas Ekonomi USU. Jurnal Manajemen Bisnis, 1(3), 97-102.

Kotler, P., \& Kevin, L. K. (2009). Manajemen Pemasaran Jilid 1. (Bob Sabran, Terj.). Jakarta: Erlangga

Pratiwi, K., \& Mandala, K. (2015). Pengaruh faktor budaya, sosial, pribadi, psikologis, dan bauran pemasaran terhadap keputusan pembelian kebaya bordir pada Jegeg Ayu Boutique di Kuta. E-Jurnal Manajemen, 4(11). Retrieved from https://ojs.unud.ac.id/index.php/Man 
Iwan Siswanto, dkk

ajemen/article/view/14671

Sugiyono. (2012). Metode Penelitian Kuantitatif, Kualitatif dan $R \& D$. Bandung: Alfabeta

Suprayitno, A, Rochaeni, S., \& Purnomowati, R. (2015). Pengaruh faktor budaya, sosial, pribadi, dan psikologi konsumen terhadap keputusan pembelian pada restoran gado-gado boplo (Studi kasus: restoran gado-gado Boplo Panglima Polim Jakarta Selatan). Agribusiness Journal, 9(2), 177-214. https://doi.org/10.15408/aj.v9i2.529 3

Suryani, T. (2008). Perilaku Konsumen: Implikasi pada Strategi Pemasaran. Yogyakarta: Graha Ilmu 